\title{
Differences in Age-distribution, Oncological Diagnoses and Stage in Roma and Non-Roma Cancer Patients Registered at the Outpatient Oncology Department Poprad in 2014 and 2015 - a Retrospective Study
}

\author{
Rozdiely vo vekovej distribúcii, onkologických diagnózach a štádiu \\ ochorenia medzi rómskymi a nerómskymi onkologickými pacientmi \\ registrovanými na ambulantnom onkologickom oddelení \\ v Poprade v rokoch 2014 a 2015 - retrospektívna štúdia
}

\author{
Reckova M. ${ }^{1,2}$, Mardiak J. ${ }^{1}$, Beniak J. ${ }^{2}$, Kakalejcik M. ${ }^{2}$, Medvecova L. ${ }^{2}$, Cingelova S. ${ }^{1}$, Mego M. ${ }^{1}$ \\ $12^{\text {nd }}$ Department of Medical Oncology, Faculty of Medicine, Comenius University, National Cancer Institute, Bratislava, Slovak Republic \\ ${ }^{2}$ POKO Poprad, s.r. o., Slovak Republic
}

\begin{abstract}
Summary
Background: Roma (Gypsies) constitute the largest ethnic minority in Slovakia. Although some studies have reported a higher prevalence of communicable diseases in Roma, there have been no studies on cancer prevalence in Roma. The aim of this study was to compare differences in age at diagnosis, oncological diagnoses, and stage between Roma and non-Roma patients registered at a single oncology outpatient department in Eastern Slovakia where substantial numbers of Roma patients are treated. Patients and Methods: Roma and non-Roma cancer patients were identified based on the judgement of both the treating physician and nurse. Age at diagnosis, oncology diagnoses, and disease stage were compared between Roma and non-Roma patients. Results: Thirty Roma and 702 non-Roma cancer patients were identified. The age distribution at diagnosis was not statistically different between Roma and non-Roma for both male and female patients. A statistically significant difference was detected in the number of Roma men having lung cancer (risk ratio - RR 0.19; 95\% Cl 0.13-0.35; $\mathrm{p}<0.01$ ), and more Roma women had kidney cancer ( $R R 0.16 ; 95 \% \mathrm{Cl} 0.05-0.69 ; \mathrm{p}=0.01$ ). There were numerically more Roma patients diagnosed with TNM stage IV disease. Significantly more Roma men were diagnosed with stage IV disease than with stage I-III disease. Conclusion: The data suggest that differences in cancer type exist between Roma and non-Roma patients. Larger population-based studies directed at analyzing for differences between Roma and non-Roma cancer patients are warranted.
\end{abstract}

Key words

Roma - neoplasms - histology - stage
The authors declare they have no potential conflicts of interest concerning drugs, products, or services used in the study.

Autoři deklarují, že $v$ souvislosti s předmětem studie nemaji žádné komerční zájmy.

The Editorial Board declares that the manuscript met the ICMJE recommendation for biomedical papers.

Redakční rada potvrzuje, že rukopis práce splnil ICMJE kritéria pro publikace zasilané do biomedicínských časopisů.

$\equiv^{\circ}$

Maria Reckova, MD

POKO Poprad, s. r. o.

Mnohelova 2

05801 Poprad

Slovak Republic

e-mail:mreckova@gmail.com

Submitted/Obdrženo: 9. 7. 2016

Accepted/Přijato: 5. 10. 2016 
Súhrn

Východiská: Rómovia tvoria jednu z najväčších etnických minoritných skupín na Slovensku. Existujú údaje o vyššej prevalencii prenosných ochorení u Rómov, avšak údaje o nádorových ochorenia chýbajú. Cielom súčasnej štúdie bolo porovnanie rozdielov vo veku v čase diagnózy, výskyte onkologických diagnóz a štádiu ochorení medzi rómskymi a nerómskymi pacientami, ktorí boli registrovaní na jednom ambulantnom onkologickom pracovisku na východnom Slovensku, kde je liečená značná čast' rómskych pacientov. Pacienti a metódy: Rómski a nerómski onkologickí pacienti boli identifikovaní na základe spoločného úsudku ošetrujúceho lekára a zdravotnej sestry. Vek v čase diagnózy, jednotlivé onkologické diagnózy a štádium ochorenia boli porovnané medzi rómskymi a nerómskymi pacientami. Výsledky: Identifikovaných bolo 30 rómskych a 702 nerómskych pacientov. Veková distribúcia v čase diagnózy nebola štatisticky signifikantne odlišná medzi rómami a nerómami, tak u mužov, ako aj u žien. Štatisticky signifikantne viac rómskych mužov malo nádory plúc (pomer rizík - RR 0,19; $95 \% \mathrm{Cl} 0,13-0,35 ; \mathrm{p}<0,01$ ), zatial'̌co štatisticky signifikantne viac rómskych žien malo nádory obličiek (RR 0,$16 ; 95 \% \mathrm{Cl} 0,05-0,69 ; \mathrm{p}=0,01)$. Numericky viac Rómov bolo diagnostikovaných v IV. štádiu ochorenia. Pri porovnaní štádia I-III vs. IV, štatisticky signifikantne viac rómskych mužov bolo diagnostikovaných v IV. štádiu. Záver: Na základe našich údajov predpokladáme, že existujú rozdiely v typoch nádorových ochorení medzi rómskymi a nerómskymi pacientami. Potrebné je uskutočnenie väčších populačných štúdií s cielom analýzy rozdielov medzi rómskymi a nerómskymi onkologickými pacientami.

Klúčové slová

Rómovia - nádory - histológia - štádium

\section{Introduction}

The Roma (Gypsies) constitute the largest ethnic minority. With their origins in Northern India, they now live in many countries throughout the world [1]. It is estimated that as many as 12 millon Roma live in the world, of which about 6 million live in Central and Eastern Europe. There are unofficial estimates that more than 400,000 Roma live in
Slovakia, however in the official Slovak Census only about 105,738 people identified themselves as being Roma in the last Census in 2011 [2]. Much of the Roma history in Europe has been characterised with persecution by non-Roma and nowadays, many Roma deny their ethnic identity [1]. Thus, there is a lack of reliable official data on the exact number of Roma.
Most of the published studies on Roma health were community-based studies or anecdotal evidence and it is practically impossible to generalise such findings. The available evidence suggests a higher predisposition of Roma to outbreaks of infectious diseases, especially those associated with unsanitary conditions and low rate of vaccination. Evidence exists about outbreaks of hepatitis $A$,
Tab. 1. Age-distribution of Roma and non-Roma male patients treated at the POKO Poprad in 2014 and 2015.

\begin{tabular}{|l|c|c|}
\hline $\begin{array}{l}\text { Age at } \\
\text { diagnosis } \\
\text { (years) }\end{array}$ & $\begin{array}{c}\text { Roma patients } \\
\text { absolute number } \\
(\%)\end{array}$ & $\begin{array}{c}\text { Non-Roma patients } \\
\text { absolute number } \\
(\%)\end{array}$ \\
\hline $20-29$ & $0(0.0)$ & $5(1.5)$ \\
\hline $30-39$ & $0(0.0)$ & $12(3.6)$ \\
\hline $40-49$ & $2(13.3)$ & $20(6.1)$ \\
\hline $50-59$ & $5(33.3)$ & $71(21.5)$ \\
\hline $60-69$ & $5(33.3)$ & $106(32.1)$ \\
\hline $70-79$ & $2(13.3)$ & $84(25.5)$ \\
\hline$\geq 80$ & $1(6.7)$ & $32(9.7)$ \\
\hline sum & $15(100.0)$ & $330(100.0)$ \\
\hline mean & 62.0 & 64.0 \\
\hline SD & 11.1 & 12.7 \\
\hline min. & 46 & 17 \\
\hline max. & 86 & 92 \\
\hline median & 64 & 65 \\
\hline p = 0.56 & & \\
\hline SD - standard deviation & \\
\hline
\end{tabular}

Tab. 2. Age-distribution of Roma and non-Roma female patients treated at the POKO Poprad in 2014 and 2015.

\begin{tabular}{|l|c|c|}
\hline $\begin{array}{l}\text { Age at } \\
\text { diagnosis } \\
\text { (years) }\end{array}$ & $\begin{array}{c}\text { Roma patients } \\
\text { absolute number } \\
(\%)\end{array}$ & $\begin{array}{c}\text { Non-Roma patients } \\
\text { absolute number } \\
(\%)\end{array}$ \\
\hline $20-29$ & $1(6.7)$ & $2(0.5)$ \\
\hline $30-39$ & $1(6.7)$ & $20(5.4)$ \\
\hline $40-49$ & $3(20.0)$ & $25(6.7)$ \\
\hline $50-59$ & $3(20.0)$ & $71(19.1)$ \\
\hline $60-69$ & $5(33.3)$ & $127(34.2)$ \\
\hline $70-79$ & $1(6.7)$ & $83(22.3)$ \\
\hline$\geq 80$ & $1(6.7)$ & $44(11.8)$ \\
\hline sum & $15(100.0)$ & $372(100.0)$ \\
\hline mean & 57.4 & 64.0 \\
\hline SD & 14.3 & 13.1 \\
\hline min. & 27 & 23 \\
\hline max. & 82 & 93 \\
\hline median & 58 & 66 \\
\hline p = 0.06 & & \\
\hline SD - standard deviation & \\
\hline
\end{tabular}


poliomyelitis and measles, and a higher prevalence of tuberculosis in Roma communities [1,3-12]. Data on non-communicable and chronic diseases in Roma suggest higher rates when compared with the majority population [3]. Higher rates of diabetes mellitus and obesity, high blood pressure, end-stage renal disease and metabolic syndrome have been reported in Roma when compared with non-Roma [13-18]. Risky health behaviour was observed in Roma and it has been reported that Roma consume high amounts of animal fat and low amounts of fruits and vegetables [19]. The unwillingness of Roma to be active in activities connected with disease prevention and general health promotion and a high prevalence of cigarette smokers was also observed [19].

There have been disparities reported in treatment outcomes and biology of oncology diseases in different racial and ethnic groups. Oncology diseases have been practically unstudied in Roma populations and only one study from the Czech Republic reported on the incidence of cervical cancer, which was 26.2 per 100,000 non-Roma women, but only 2.4 per 100,000 Roma women [1]. The aim of our study was to compare age at diagnosis, oncological diagnoses and stage at initial diagnosis in Roma and non-Roma oncology patients treated at the Outpatient Oncology Department in Poprad (POKO Poprad) in the years 2014 and 2015.

\section{Patients and Methods \\ Patients}

The patients registered and treated at the POKO Poprad were selected as there is a substantial number of Roma people who live in the Spis region (Poprad and Kezmarok districts) and treated at the POKO Poprad.

In order to identify Roma patients registered at the POKO Poprad, a common judgement by the treating oncologist and nurse to indicate who was Roma was used.

All patients registered at the POKO Poprad with malignant oncological disease from January 2014 to December 2015 were included in the study.

Tab. 3. Oncological diagnoses in Roma and non-Roma male patients treated at the POKO Poprad in 2014 and 2015.

\begin{tabular}{|c|c|c|c|}
\hline $\begin{array}{l}\text { Diagnoses } \\
\text { according } \\
\text { to ICD-10* }\end{array}$ & $\begin{array}{l}\text { Roma patients } \\
\text { absolute number } \\
\text { (\%) }\end{array}$ & $\begin{array}{c}\text { Non-Roma patients } \\
\text { absolute number } \\
\text { (\%) }\end{array}$ & $\mathbf{p}$ \\
\hline $\mathrm{C} 00-\mathrm{C} 14+\mathrm{C} 32$ & $0(0.0)$ & $24(7.3)$ & 1.00 \\
\hline C15 & $0(0.0)$ & $5(1.5)$ & 1.00 \\
\hline C16 & $1(6.7)$ & $18(5.5)$ & 0.58 \\
\hline C17-C20 & $2(13.3)$ & $64(19.4)$ & 0.75 \\
\hline $\mathrm{C} 22$ & $0(0.0)$ & $7(2.1)$ & 1.00 \\
\hline $\mathrm{C} 23-\mathrm{C} 24, \mathrm{C} 26$ & $0(0.0)$ & $3(0.9)$ & 1.00 \\
\hline $\mathrm{C} 25$ & $0(0.0)$ & $11(3.3)$ & 1.00 \\
\hline C34 & $10(66.6)$ & $42(12.7)$ & $\begin{array}{c}<0.01^{* *} \\
\operatorname{RR} 0.19(0.13-0.35)\end{array}$ \\
\hline C40-41 & $0(0.0)$ & $1(0.3)$ & 1.00 \\
\hline $\mathrm{C} 43$ & $0(0.0)$ & $11(3.3)$ & 1.00 \\
\hline C44 & $0(0.0)$ & $12(3.7)$ & 1.00 \\
\hline C45-C49 & $0(0.0)$ & $1(0.3)$ & 1.00 \\
\hline $\begin{array}{l}\text { C60-C63, } \\
\text { except C61, C62 }\end{array}$ & $0(0.0)$ & $2(0.6)$ & 1.00 \\
\hline C61 & $0(0.0)$ & $33(10.0)$ & 0.38 \\
\hline C62 & $0(0.0)$ & $11(3.3)$ & 1.00 \\
\hline C64 & $1(6.7)$ & $16(4.9)$ & 0.54 \\
\hline C65-C68 & $0(0.0)$ & $11(3.3)$ & 1.00 \\
\hline $\mathrm{C} 69-\mathrm{C} 72$ & $1(6.7)$ & $6(1.8)$ & 0.27 \\
\hline C73-C75 & $0(0.0)$ & $3(0.9)$ & 1.00 \\
\hline $\mathrm{C} 76-\mathrm{C} 80$ & $0(0.0)$ & $30(9.1)$ & 0.38 \\
\hline C81-C96 & $0(0.0)$ & $12(3.7)$ & 1.00 \\
\hline C97 & $0(0.0)$ & $7(2.1)$ & 1.00 \\
\hline sum & $15(100.0)$ & $330(100.0)$ & NA \\
\hline
\end{tabular}

*International Classification of Diseases, $10^{\text {th }}$ revision, ${ }^{* *}$ statistically significant difference, NA - not-applicable, RR - relative risk

The study was approved by the Ethics Committee of the National Cancer Institute in Bratislava.

\section{Statistical methods}

Patient characteristics were tabulated. The patients' characteristics were summarised using mean, median and range for continuous variables and frequency (percentage) for categorical variables. The difference between age in Roma and non-Roma patients was tested by Student's t-test; data normality assumption was confirmed by Kolmo-
gorov-Smirnoff test. Fisher's exact test was used to evaluate the differences in oncological diagnoses and TNM stage $[20,21]$ between Roma and non-Roma. All p (probability) values presented are two-sided, and associations were considered significant if the $p$ value was $\leq 0.05$.

\section{Results}

There were 581 men and 646 women reported with diagnosis of malignant oncological disease at the POKO Poprad from 2014 to 2015 . There were 236 male 
Tab. 4. Oncological diagnoses in Roma and non-Roma female patients treated at the POKO Poprad in 2014 and 2015.

\begin{tabular}{|c|c|c|c|}
\hline $\begin{array}{l}\text { Diagnoses } \\
\text { according } \\
\text { to ICD-10* }\end{array}$ & $\begin{array}{c}\text { Roma patients } \\
\text { absolute number } \\
\text { (\%) }\end{array}$ & $\begin{array}{l}\text { Non-Roma patients } \\
\text { absolute number } \\
\text { (\%) }\end{array}$ & $\mathbf{p}$ \\
\hline C00-C14 + C32 & $0(0.0)$ & $7(1.9)$ & 1.00 \\
\hline C15 & $0(0.0)$ & $2(0.5)$ & 1.00 \\
\hline C16 & $1(6.7)$ & $11(3.0)$ & 0.96 \\
\hline C17-C20 & $2(13.3)$ & $45(12.1)$ & 1.00 \\
\hline C21 & $0(0.0)$ & $2(0.5)$ & 1.00 \\
\hline C22 & $0(0.0)$ & $4(1.1)$ & 1.00 \\
\hline$C 23-C 24, C 26$ & $0(0.0)$ & $8(2.2)$ & 1.00 \\
\hline C25 & $0(0.0)$ & $16(4.3)$ & 1.00 \\
\hline C34 & $1(6.7)$ & $23(6.2)$ & 1.00 \\
\hline C43 & $0(0.0)$ & $15(4.1)$ & 1.00 \\
\hline C44 & $0(0.0)$ & $9(2.4)$ & 1.00 \\
\hline C45-C49 & $0(0.0)$ & $2(0.5)$ & 1.00 \\
\hline C50 & $2(13.3)$ & $101(27.2)$ & 0.37 \\
\hline $\begin{array}{l}\text { C51-C58, } \\
\text { except C53, C56 }\end{array}$ & $1(6.7)$ & $25(6.7)$ & 1.00 \\
\hline C53 & $0(0.0)$ & $19(5.1)$ & 1.00 \\
\hline C56 & $2(13.3)$ & $18(4.8)$ & 1.00 \\
\hline C64 & $3(20.0)$ & $12(3.2)$ & $\begin{array}{c}0.01^{* *} \\
\text { RR } 0.16(0.05-0.69)\end{array}$ \\
\hline C65-C68 & $0(0.0)$ & $5(1.3)$ & 1.00 \\
\hline C69-C72 & $1(6.7)$ & $7(1.9)$ & 0.27 \\
\hline C73-C75 & $0(0.0)$ & $6(1.6)$ & 1.00 \\
\hline C76-C80 & $2(13.3)$ & $23(6.2)$ & 0.25 \\
\hline C81-C96 & $0(0.0)$ & $5(1.3)$ & 1.00 \\
\hline C97 & $0(0.0)$ & $7(1.9)$ & 1.00 \\
\hline sum & $15(100.0)$ & $372(100.0)$ & NA \\
\hline
\end{tabular}

*International Classification of Diseases, $10^{\text {th }}$ revision, ${ }^{* *}$ statistically significant difference, NA - not-applicable, RR - relative risk

and 259 female patients, who were not treated at the POKO Poprad but elsewhere, were excluded. Finally, we identified 30 Roma (15 male, 15 female) and 702 non-Roma (330 male, $372 \mathrm{fe}-$ male) patients. Patient's age distribution at diagnosis, oncological diagnosis and stage at initial diagnosis are compared between Roma and non-Roma, and presented separately for male and female patients (Tab. 1-6).

There was no statistically significant difference in age distribution at diag- nosis in male and female patients when comparing Roma and non-Roma. However, numerically, more Roma were diagnosed with cancer in the age group 40-59 years and more non-Roma were diagnosed with cancer in the age group 70-79 years of age (Tab. 1, 2).

Colorectal and lung cancers were the most frequent oncological diagnoses in both Roma and non-Roma male patients (Tab. 3, 4). Colorectal and breast cancer were the most frequent oncological diagnoses in both Roma and non-Roma female patients. In addition, ovarian and kidney cancer, and cancer of unknown primary were the most frequent oncological diagnoses of Roma female patients. Statistically significant differences were detected with more Roma men having lung cancer (risk ratio - RR 0.19; $95 \% \mathrm{Cl}$ 0.13-0.35; $\mathrm{p}<0.01$ ) and more Roma women having kidney cancer (RR 0.16; 95\% Cl 0.05-0.69; $\mathrm{p}=0.01$ ).

Disease stage at initial diagnosis was compared for all patients except the patients with central nervous (CNS) tumours, tumours of unknown primary and haematologic malignancies because no TNM staging system is used for these oncological diagnoses. Numerically, there were more Roma patients diagnosed at TNM stage IV disease (Tab. 5, 6). More non-Roma patients were diagnosed with stages I-III, except non-Roma female patients who, numerically, had less stage I disease when compared with Roma. The differences in TNM stage at diagnosis were statistically significantly different when comparing stages I-III vs. IV in Roma and non-Roma for men but not for women.

\section{Discussion}

Roma belong to the largest ethnic minority in Central and Eastern Europe. Insufficient information exists about the exact number of Roma living in Slovakia. There is evidence that the Roma population is stigmatised and it might be one of the reasons why only about $2 \%$ of the Slovak population indicated their Roma ethnicity in the last Slovak Census in 2011. Based on data from Atlas of Roma Communities 2013 it is, however, estimated that more than 400,000 Roma live in Slovakia [22]. According to the Census of the Statistical Office in Slovak Republic in 2011, the total population of Slovakia was $5,404,322$ inhabitants [2]. The Roma population, according to Atlas of Roma Communities 2013, is thus 7.45\%. The highest number of villages and towns with a Roma community is in the county of Banska Bystrica, followed by the county of Kosice and county of Presov, and the smallest number of municipalities with a Roma community is in the counties of Bratislava and Zilina [22]. 
Tab. 5. The stage distribution in Roma and non-Roma male patients treated at the POKO Poprad in 2014 and 2015 (except tumors of central nervous system, unknown primary and hematologic malignancies).

\begin{tabular}{l|c|c|}
\hline $\begin{array}{l}\text { Stage } \\
\text { [21] }\end{array}$ & $\begin{array}{c}\text { Roma patients } \\
\text { absolute number } \\
(\%)\end{array}$ & $\begin{array}{c}\text { Non-Roma patients } \\
\text { absolute number } \\
\text { (\%) }\end{array}$ \\
\hline I & $1(7.1)$ & $69(24.6)$ \\
\hline II & $1(7.1)$ & $48(17.0)$ \\
III & $2(14.3)$ & $43(15.3)$ \\
IV & $10(71.5)$ & $121(43.1)$ \\
\hline sum & $14(100.0)$ & $281(100.0)$ \\
\hline P = 0.05; RR 1.66 (0.96-2.15); stage I, II, III vs. IV \\
\hline RR- risk ratio
\end{tabular}

Tab. 6. The stage distribution in Roma and non-Roma female patients treated at the POKO Poprad in 2014 and 2015 (except tumors of central nervous system, unknown primary and hematologic malignancies).

\begin{tabular}{l|c|c}
\hline $\begin{array}{l}\text { Stage } \\
{[21]}\end{array}$ & $\begin{array}{c}\text { Roma patients } \\
\text { absolute number } \\
(\%)\end{array}$ & $\begin{array}{c}\text { Non-Roma patients } \\
\text { absolute number } \\
\text { (\%) }\end{array}$ \\
\hline I & $6(42.9)$ & $108(32.0)$ \\
\hline II & $0(0.0)$ & $74(22.0)$ \\
III & $2(14.2)$ & $61(18.1)$ \\
IV & $4(42.9)$ & $94(27.9)$ \\
\hline sum & $12(100.0)$ & $337(100.0)$ \\
\hline P = 0.74; RR 1.20 (0.40-2.39); stage I, II, III vs. IV \\
\hline
\end{tabular}

The POKO Poprad takes care of people living in the districts of Poprad and Kezmarok in Presov County where a substantial Roma population resides. In total there are 151,429 people living in the district of Poprad and Kezmarok and 30,096 are Roma people (19.9\%) [22].

There were 581 male and 646 female patients with malignant oncological diagnoses registered in the National Oncology Registry of Slovakia (NOR) for Poprad and Kezmarok districts in 2014 and 2015. There were 236 male and 259 female patients were registered in the NOR for Poprad and Kezmarok district, but they were not registered and treated at the POKO Poprad, and because we did not have information about patients' ethnicity, they were excluded from the analysis. Finally, 30 Roma (4.1\%) and 702 non-Roma (95.9\%) cancer patients were identified for analysis. There were 30 Roma out of $15,048$ adult Roma people ( $0.2 \%)$, and 718 non-Roma out of 90,999 adult non-Roma people $(0.8 \%)$ were registered and treated with a cancer diagnosis at the POKO Poprad.

There are several explanations of the lower proportion of Roma cancer patients registered at the POKO Poprad identified in our study.

First of all we have to take into account that we might not be able to identify all Roma cancer patients treated at our clinic. No data on ethnicity of cancer patients exist in the medical records at the POKO Poprad. In this retrospective study, the identification of Roma cancer patients was based on common judgement by the treating oncologist and nurse and there is a possibility that some Roma patients could be missed by this method of identification.

There are only adult patients treated at POKO Poprad. Most of the cancers treated at POKO Poprad are diagnosed and treated in older age. Mean and median age of the patients treated at the POKO Poprad in 2014 and 2015 was 63.7 and 65 years, resp. It is estimated that mean age and estimated life expectancy in Roma is 10 to 15 years lower than non-Roma, resp. [1,22,23]. Because the Roma population is generally younger we could expect that fewer Roma live to an age when cancer can be diagnosed and treated.

Five models, which include genetic-racial, behavioural, psychosocial, socio-economic and structural-constructivist model, can comprehensively explain racial and ethnic health differences [24].

Evidence exists that communication between Roma and healthcare workers is poor and we might suppose that Roma people participate less than non-Roma in screening programmes and diagnostic procedures $[25,26]$. Thus, we could suppose that another possibility of a lower proportion of Roma people diagnosed with cancer could be a sign of underdiagnosis of cancer in Roma.

There are certain protective factors that could be attributable to a lower number of specific cancer cases in Roma, such as early age at the first pregnancy, early start of menarche, low use of hormonal therapy, low use of alcohol in young Roma women [25]. The numbers of identified cancers were low and some cancers were not detected in our Roma patient cohort at all (e.g. cervical and prostate cancer, Tab. 3, 4). On the other hand, certain risk factors might place Roma people into a higher risk of cancer, e.g. high BMI, low physical activity, low consumption of fruits and vegetables, alcohol consumption, smoking history $[25,27]$. There is a strong connection between smoking history and lung cancer. There is also evidence that the rate of smoking is high among Roma and this could be a reason for a high rate of lung cancer observed among Roma men. Smoking and obesity are more prevalent in Roma women and they are established risk factors for the development of kidney cancer $[28,29]$. This could be one of the explanations for a higher rate of kidney cancer observed in Roma women. Besides a higher rate of lung cancer in Roma men and kidney cancer in Roma women, we did not detect any other statistically significant difference in the rates of specific cancers between Roma and non-Roma. 
We cannot, however, exclude statistical bias that might be caused by a low number of cases that were compared.

Lastly, a biological difference might exist which puts Roma people in the lessen or non-Roma people at a higher risk of being diagnosed with cancer.

There were 769 new cancer cases registered in Poprad and Kezmarok districts in the last report of the NOR in 2009 [30]. There is an increasing number of malignancies registered in the NOR each year. We, however, identified only 1,227 new tumour cases that were registered in Poprad and Kezmarok districts in 2014 and 2015. The lower than expected number of tumour cases identified in our study could be a sign of underdiagnosis or underreporting to the NOR for Poprad and Kezmarok district in 2014 and 2015. Another possibility is a genuinely lower rate of new tumour cases in 2014 and 2015 for Poprad and Kezmarok district.

In our study, we had to exclude the patients that were registered in the NOR for Poprad and Kezmarok district but were not treated at the POKO Poprad. The exclusion was based on the fact that ethnicity could not be identified in the patients who were not registered at the POKO Poprad. The most frequent cancer diagnoses registered in the NOR for Poprad and Kezmarok district, however, were not registered at the POKO Poprad were non-melanoma skin cancers for both men (83 out of $236 ; 35.2 \%$ ) and women (126 out of $259 ; 48.6 \%)$ and prostate cancer for men (46 out of 236; $19.1 \%)$. The most probable explanation why these patients were not registered at the POKO Poprad is the fact that the patients with non-melanoma skin cancer are usually treated and followed up at dermatology clinics and some prostate cancer patients are treated and followed up at urology clinics. This could also be the case for cervical cancer as some of the early stage tumours could be followed up at the gynaecology and not oncology clinics. However only 9 out of 259 (3.9\%) female patients with cervical cancer, registered in the NOR for Poprad and Kezmarok district, but not registered at the POKO Poprad, were excluded from our analysis. We assume that these patients might have been treated and followed up by somewhere other than the oncology clinic in Poprad.

When comparing TNM stage at the initial diagnosis, numerically there were more Roma cancer patients diagnosed with stage IV disease and there were numerically more non-Roma patients diagnosed with earlier stages of diseases except more Roma female patients who were diagnosed with stage I disease. The differences in TNM stage at diagnosis were statistically significantly different when comparing stages I-III vs. IV in Roma and non-Roma for men but not for women. Because we suppose that Roma people are less compliant with screening and treatment programmes and there is poorer communication between Roma and healthcare workers, we would expect that Roma people would be diagnosed with cancer in later stages and that is consistent with our findings. We, however, must take into account that our study was only carried out in one oncology centre and the number of analysed patients is rather small for making any strong conclusions.

\section{Conclusion}

In this retrospective study from a single oncology outpatient department in Eastern Slovakia, in which a substantial number of Roma patients are treated, we demonstrated a statistically significantly higher rate of lung cancer in Roma male patients and kidney cancer in Roma female patients. Numerically, more Roma cancer patients were diagnosed at a more advanced TNM stage, both in men and women. Statistically significantly more Roma men were diagnosed at stage IV when compared to stages I-III vs. IV.

A prospective multicentre study that would study the differences between Roma and non-Roma cancer patients is warranted.

\section{References}

1. Koupilová l, Epstein H, Holčík J et al. Health needs of the Roma population in the Czech and Slovak Republics. Soc Sci Med 2001; 53(9): 1191-1204.

2. Matlovicova K, Matlovic R, Musinka A et al. The Roma population in Slovakia. Basic characteristics of the Roma population with emphasis on the spatial aspects of its differentiation. In: Penczse J, Radics Z (eds). Roma population on the peripheries of the Visegrad countries.
Spatial Trends and social challenges. Debrecen 2012: 77-104.

3. Cook B, Wayne FG, Valentine A et al. Revisiting the evidence on health and health disprities among the Roma: a systematic review 2003-2012. In J Public Health 2013; 58(6): 885-911. doi: 10.1007/s00038-013-0518-6.

4. Rosicova K, Reijneveld SA, Madarasova-Geckova A et al. Inequalities in mortality by socioeconomic factors and Roma ethnicity in the two biggest cities in Slovakia: a multilevel analysis. Int J Equity Health 2015; 14(1): 123. doi: 10.1186/s12939-015-0262-z.

5. Rosicova K, Madarasova-Geckova A, van Dijk JP et al. Regional socioeconomic indicators and ethnicity as predictors of regional infant mortality rate in Slovakia. Int J Public Health 2011; 56(5): 523-531. doi: 10.1007/s00038010-0199-3

6. Casals M, Pila P, Langohr K et al. Incidence of infectious diseases and survival among the Roma population: a longitudinal cohort study. Eur J Public Health 2011; 22(2): 262-266. doi: 10.1093/eurpub/ckq204.

7. Gyarmarthy VA, Neaigus A, Ujhelyi E. Vulnerability to drug-related infections and co-infections among injecting drug users in Budapest, Hungary. Eur J Public Health 2009; 19(3): 260-265. doi: 10.1093/eurpub/ckp009.

8. Vantarakis A, Nearxou A, Pagonidis D et al. An outbreak of hepatitis $\mathrm{A}$ in Roma populations living in three prefectures in Greece. Epidemiol Infect 2010; 138(7): 1025-1031. doi: 10.1017/S0950268809991257.

9. Kojouharova M, Zuber PL, Gyurova S et al. Importation and circulation of poliovirus in Bulgaria in 2001. Bul World Health Organ 2003; 81(7): 476-481.

10. Maduma-Butshe A, McCarthy N. The burden and impact of measles among the Gypsy-Traveller communities, Thames Valle, 2006-09. J Public Health 2013; 35(1): 27-31. doi: 10.1093/pubmed/fds052.

11. Dostal M, Topinka J, Sram RJ. Comparison of the health of roma and non-Roma children living in the district of Teplice. Int J Public Health 2010; 55(5): 435-441. doi: 10.1007/s00038-010-0133-8.

12. Monasta L, Andersson N, Ledogar RJ et al. Minority health and small numbers epidemiology: a case study of living conditions and the health of children in 5 foreign Roma camps in Italy. Am J Public Health 2008; 98(11): 2035-2041. doi: 10.2105/AJPH.2007.129734.

13. Hidvegi T, Hetyesi K, Biro L et al. Screening for metabolic syndrome within a minority ethnic group (adult Gypsy people) in Hungary. Bratisl Lek Listy 2011; 113(12): 721-724.

14. Vozarova de Courten B, de Courten M, Hanson RL et al. Higher prevalence of type 2 diabetes, metabolic syndrome and cardiovascular diseases in gypsies than in non-gypsies in Slovakia. Diabetes Res Clin Pract 2003; 62(2): 95-103.

15. Zivkovic TB, Marjanovic M, Prgomelja S et al. Screening for diabetes among Roma people living in Serbia. Croat Med J 2010; 51(2): 144-150.

16. Zjelko HM, Skaric-Juric T, Narancic NS et al. Traditional CVD risk factors and socio-economic deprivation in Roma minority population of Croatia. Coll Antropol 2008; 32(3): 667-676.

17. Gualdi-Russo E, Zironi A, Dallari GV et al. Migration and health in Italy: a multiethnic adult sample. J Travel Med 2009; 16(2): 88-95. doi: 10.1111/j.1708-8305.2008.00 280.x.

18. Carrasco-Garrido P, de Andrés AL, Barrera VH et al. Health status of Roma women in Spain. Eur J Public Health 2011; 21(6): 793-798. doi: 10.1093/eurpub/ckq153.

19. Ginter E, Krajcovicova-Kudlackova M, Kacala O et al. Health status of Romanies (Gypsies) in the Slovak Republic and in the neighboring countries. Bratis Lek Listy 2001; 102(10): 479-484.

20. Sobin LH, Gospodarowicz MK, Wittekind C (eds). TNM classification of malignant tumors. 7th ed. Oxford: Wiley-Blackwell 2009. 
21. Novak J, Fabian P. Comments on the TNM classification of malignant tumors - 7th edition. Klin Onkol 2011; 24(2): 149-150

22. Musinka A, Skobla D, Hurrle J et al. Atlas of Roma Communities in Slovakia 2013. Bratislava: UNDP 2014.

23. Popper M, Szeghy P, Sarkozy S. Health and the Roma community: analysis of the situation in Europe. Madrid 2009

24. Dressler W, Oths KS, Gravlee C. Race and ethnicity in public health research: models to explain health disparities. Annu Rev Anthropol 2005; 34: 231-252.
25. Cook B, Wayne FG, Valentine A et al. Revisiting the evidence on health and health disparities among the Roma: a systematic review 2003-2012. In J Public Health 2013; 58(6): 885-911. doi: 10.1007/s00038-013 0518-6.

26. Belak A. Health-system limitations of Roma health in Slovakia. A qualitative study. Košice: Equilibria, s.r.o. 2013. 27. Sedlakova D. Low socioeconomic status and unhe althy lifestyle lead to high morbidity in young Roma of East Slovakia (editorial). Centr Eur J Public Health 2014; 22 (Suppl): S3- S5.
28. Carrasco-Garrido P, de Andres AL, Barrera VH et al. Health status of Roma women in Spain. Eur J Public Health 2011: 21(6): 793-798 doi: 10.1093/eurpub/ckq153.

29. NCCN Clinical Practice in Oncology (NCCN Guidelines) Kidney Cancer NCCN Evidence BlocksTM Version 3.2016 NCCN.org. [online] Available from: https://www. nccn.org/professionals/physician_gls/pdf/kidney_ blocks.pdf. Accessed 7 Jul 2016

30. Cancer incidence in the Slovak Republic. Publisher National Health Information Center. Bratislava: Vydavatel'stvo NCZI 2015 